\title{
HOW WILL DEFINED CONTRIBUTION \\ PENSION PLANS AFFECT \\ RETIREMENT INCOME?
}

\author{
Andrew A. Samwick \\ Jonathan Skinner
}

Working Paper 6645

http://www.nber.org/papers/w6645

\section{NATIONAL BUREAU OF ECONOMIC RESEARCH 1050 Massachusetts Avenue}

Cambridge, MA 02138

July 1998

We thank Jon Gruber, Alan Gustman, Olivia Mitchell, John Shoven, and Celia Silberman for helpful discussions; Arthur Kennickell, Bob Denk, and Bob Peticolas for assistance with the SCF and PPS data; Jeremy Siegel for the asset return data; and seminar participants at the APPWP/CEPR "Public Policy Towards Pensions" conference, the Center for Pension and Retirement Research, the Institute for Fiscal Studies, Dartmouth College, Columbia University, and the University of Wisconsin for useful comments. Financial support from the Association of Private Pension and Welfare Plans, the Center for Economic Policy Research, and the National Institute on Aging through the NBER is gratefully acknowledged. Any opinions expressed are those of the author and not those of the National Bureau of Economic Research.

(C) 1998 by Andrew A. Samwick and Jonathan Skinner. All rights reserved. Short sections of text, not to exceed two paragraphs, may be quoted without explicit permission provided that full credit, including $(\mathcal{C}$ notice, is given to the source. 
How Will Defined Contribution Pension

Plans Affect Retirement Income?

Andrew A. Samwick and Jonathan Skinner

NBER Working Paper No. 6645

July 1998

JEL No. J32, J14, D31

\section{ABSTRACT}

How has the emergence of defined contribution pension plans, such as $401(\mathrm{k}) \mathrm{s}$, affected the financial security of future retirees? We consider this question using a detailed survey of pension formulas in the Survey of Consumer Finances. Our simulations show that average and median pension benefits are higher under defined contribution plans that for defined benefit plans. Defined benefit plans are slightly better at providing minimum benefits, but for plausible values of risk aversion, a defined contribution plan drawn randomly from those available in 1995 is still preferred to a defined benefit plan drawn randomly from those available in 1983 . This result is robust to different assumptions regarding the spending of defined contribution balances between jobs, equity rates of return, and the date of retirement. In short, we suggest that defined contribution plans can strengthen the financial security of retirees.

Andrew A. Samwick 6106 Rockefeller Hall

Department of Economics

Dartmouth College

Hanover, NH 03755-3514

and NBER

samwick@dartmouth.edu
Jonathan S. Skinner

6106 Rockefeller Hall

Department of Economics

Dartmouth College

Hanover, NH 03755-3514

and NBER

jonathan.skinner@dartmouth.edu 


\section{Introduction}

Two decades ago, most workers with pensions had a defined benefit (DB) plan. The employer made necessary contributions and investments to meet promised pension benefit payments when the employee retired. By 1993, the tide had turned; more than half of covered employees participated primarily in defined contribution (DC) plans such as 401(k) plans (EBRI, 1997). Under DC plans, the employee and employer make regular payments into investment accounts that accumulate tax-free until retirement. The employee typically bears the primary responsibility for investing the contributions and for making supplemental contributions to ensure a satisfactory retirement income. This dramatic shift is most noticeable among small employers, but it is also present in large employers, state and local governments (Dow Jones, 1995), and other countries such as Canada and the United Kingdom (Flavelle, 1997; Martinson, 1998).

This fundamental shift in the nature of pension saving has not gone unnoticed by observers in the popular press and in academia. Aside from anecdotal information, however, there is surprisingly little information about the relative adequacy of defined contribution plans. Consider three fundamental yet largely unanswered questions about this shift. First, are DC plans, compared to DB plans, adequate in providing for a comfortable retirement pension? Some financial writers have suggested that the DC pension system is a crisis waiting to happen when current generations, having made minimal (or no) contributions to their DC plan, retire with inadequate pension asset balances (Ferguson and Blackwell, 1995; Willette, 1995).

Second, will employees end up with inadequate retirement benefits because when switching jobs, they use their DC asset balances to buy houses, boats, or other purchases rather than reinvesting them in another retirement account (Schultz, 1993)? Alternatively, will they 
erode the value of their accounts by borrowing against the accounts before retirement (Crenshaw, 1997)? Even if contribution rates and investment returns are adequate, retirees could face financial distress if they spend much of the balances while young, either during job transitions or by borrowing.

Third, will DC plans expose workers to more risk? The risk can come from two sources. One source is the uncertainty about rates of return on investments in the DC accounts. Employees may be uninformed about their investment choices, lack the confidence to manage their own retirement money, or suffer from poor stock market and bond returns (Ferguson and Blackwell, 1995; Flaherty, 1997). The other source of uncertainty is related to variability in future earnings. Defined contribution plans have payouts based on a worker's average earnings over a whole career but lack explicit mechanisms to pool earnings risk across workers. Benefits from DB plans are typically based on earnings during the last few years of service, which are more risky than a career average, but often include provisions such as minimum benefits and maximum benefit caps that reduce risk in a cross-section of workers (Bodie, Marcus, and Merton, 1988).

These questions have proved difficult to evaluate in the past because of the substantial heterogeneity in DB and DC plans across individual firms and in the contribution and investment decisions of workers in DC plans. In order to understand what was lost when traditional DB plans fell from prominence, we need to be able to calculate pension benefits under a broad range of labor and capital market scenarios for a representative sample of households with pensions. We make our comparison using the supplemental Pension Provider Survey (PPS) to the Survey of Consumer Finances (SCF) from 1983 and the self-reported characteristics of pension plans in the subsequent SCFs through 1995. 
Using the methodology in Samwick (1993a), we estimate the "average" pension benefit by running a broad range of simulated earnings histories through the weighted sample of DB plans from 1983 (prior to the proliferation of DC plans) and DC plans from 1995. The detailed pension formulas from the PPS combined with simulated earnings histories and historical asset returns allow us to determine whether defined contribution plans are more or less generous, and more or less risky, than defined benefit plans, given plausible assumptions about investment and earnings risk faced by workers over their remaining working lives.

The results suggest that defined contribution plans are not the ticking time bomb that many fear. Using actual contribution and investment allocations from a nationally representative sample, mean and median DC pension benefits are substantially higher than the corresponding DB benefits. If some DC plans in 1995 did not provide adequately for retirement, then neither did many DB plan in 1983. This result is robust to changes in simulated equity rates of return, productivity growth, and earnings uncertainty.

Even when employees change jobs before retirement, pension benefits still tend to be lower under the older DB plans because of the backloading of pension accruals. Our simulations show that employees with DC plans need only roll over approximately 25 percent of distributions received early in their careers and 50 percent of distributions received late in their careers in order to maintain parity with what their benefits would have been under traditional DB plans.

Finally, the evidence suggests that DC plans are indeed more risky, in the sense that the variance of retirement income is greater than for DB plans. However, the expected returns are also higher, so that DC plans provide higher levels of benefits in all but the bottom quintile of the distribution of pension income. We calculate that a typical worker who was continuously 
employed between ages 31 and 65 would prefer a randomly chosen DC plan from 1995 to a randomly chosen DB plan from 1983, even with a coefficient of relative risk aversion as high as 12.

\section{The Increasing Importance of Defined Contribution Plans}

Defined contribution plans have experienced rapid growth in the past two decades. The percentage of workers listing DC plans as their primary pension has risen from 13 percent in 1975 to 33 percent in 1988 and 42 percent in 1993. A large fraction of this growth comes from the increase in coverage of $401(\mathrm{k})$ plans. Participants in such plans grew from 19 percent of active private sector participants in 1984 to 52 percent in 1993 (EBRI, 1997). Papke (1997) finds that some of the DC plan growth has come at the expense of terminated DB plans, particularly among smaller employers who are most likely to find DB administrative costs onerous.

Why have DC plans become so popular? Beller and Lawrence (1992) identify three factors that may have facilitated the shift from DB plans to DC plans. The first factor is the relative decline in employment at large, unionized manufacturing firms, which tend to favor DB plans, relative to small, non-unionized service firms, which tend to favor DC plans. The second factor is the succession of legislation since the Employee Retirement Income Security Act of 1974 (ERISA) that has increased the relative cost and complexity of DB plans and enhanced the tax advantages of DC plans. ${ }^{1}$ The third factor is the growing acceptance of DC plans as saving vehicles by employees themselves. In particular, workers who expect to change jobs frequently

\footnotetext{
${ }^{1}$ While both DB and DC plans are subject to nondiscrimination rules regarding the distribution of pension wealth across employees, the employer's responsibility for meeting the promised benefit payments under a DB plan generates considerable regulations on the timing of the funding of those promises. Some of those regulations, combined with the recent bull market in equities, have prevented firms from making substantial contributions to DB plans, thereby denying companies with DB plans current tax savings.
} 
over their careers might favor DC plans over DB plans because they provide access to better benefits for short-term workers. Each of these factors further suggests that the DC plan will remain the dominant form of pension coverage for current and future generations of workers.

Will these emerging DC plans provide retirement benefits comparable to the DB plans that they appear to be supplanting? The enormous variation in pension plans across firms makes answering this question difficult. In a DB plan, the firm typically promises to pay the worker a nominal annuity based on a set of formulas related to the worker's age, years of service, and final average pay. These formulas vary considerably across pension plans (Gustman and Steinmeier, 1989). Final average pay may be the average of the last few years of earnings but is more often the average of the highest few years or the highest consecutive years during the last few years. (The distinction matters when wages are stochastic or decline later in the work life.) Many plans specify a replacement rate per year of service, but the replacement rate varies substantially across firms. ${ }^{2}$ Other plans pay a flat rate of benefits in dollar terms per year of service worked (Kotlikoff and Smith, 1983).

Some DB plans are also integrated with Social Security to varying degrees, and most have more than one formula that can be operative for a given worker. Finally, there are differences in how DB plans treat early retirement, both in terms of what is considered a "normal" retirement date and the extent to which benefits are reduced because of early retirement. This heterogeneity in DB plans thus makes it difficult to characterize what average pension benefits would be in the DB "regime" prior to the rise of DC plans. ${ }^{3}$

\footnotetext{
2 For example, if the replacement rate is 1.5 percent per year of service and the number of years of service is 20 , the replacement rate would be 30 percent of final average pay.

${ }^{3}$ The impact of these incentives on retirement from the firm has been demonstrated in various ways over the past decade or so. See, for example, Gustman and Steinmeier (1986), Stock and Wise (1990), and Samwick (1998). Woodbury (1997) discusses how the incentives in DB plans may actually be the consequence of efforts to ensure
} 
In contrast to DB plans, DC plans differ across firms along just a few dimensions. The first is whether the plan permits employee contribution rates and whether these contributions are capped. Some traditional DC plans are non-contributory, so that the employer funds the entire pension. The newer 401(k) plans are actually tax-deferred saving accounts in which employee contributions play a central role. The second dimension is the percent of the employee's pay that is contributed by the employer. In 401(k) plans, there is often both a fixed contribution rate for each employee plus a contribution that "matches" the employee's contribution. Match rates typically range from $\$ 0.10$ to $\$ 1.00$ per dollar of employee contribution and may be capped. A common example is a 50 cents on the dollar match on the employee's first six percent of salary contributed. The eventual benefits received by the worker will also vary across firms, and across workers, based on both the portfolio allocations chosen by the firm or the worker and the investment returns received in those portfolios. In the next section, we review our data source from the Survey of Consumer Finances that allows us to capture and measure this heterogeneity in both DB and DC plans.

\section{Modeling Retirement Benefits in the SCFs}

Our estimates of pension benefits are based on the household data in the Surveys of Consumer Finances (SCF) and the companion Pension Provider Surveys (PPS). Conducted triennially since 1983 by the Federal Reserve Board and other government agencies, the SCFs are designed to provide a comprehensive survey of household wealth in the United States. Each survey collects detailed information on asset and debt holdings for both a representative crosssection of households and a special sample of high-income households identified from tax

fairness in replacement rates across different types of workers based on years of service and age rather than explicit policies to manage turnover. 
returns. ${ }^{4}$ For every respondent or spouse in the first (1983) SCF sample who reported being covered by a pension, the PPS attempted to obtain the summary plan description for the plan from the pension provider (usually the employer). Approximately 73 percent of the workers reporting coverage had valid data on their plans in the PPS. ${ }^{5}$

We view the trend toward DC plans that began in the early 1980s as a change of regimes in which the typical worker who is covered by a pension will now have benefits determined by a DC plan rather than a DB plan. In order to assess what this regime change means for future retirement income, we sample plans in 1983, the earliest date during the transition for which we have comprehensive data on DB pension plans. As the transition continued, the characteristics of the sample of remaining DB plans changed considerably. The weaker plans were likely supplanted by the newer 401(k) plans, as noted above (Papke, 1997). Examining a sample of DB plans, such as those in the PPS from 1989, would overstate the generosity of DB plans before the transition began.

There have also been changes in the characteristics of DC plans during the transition. As the latest survey year, the sample of DC plans available in 1995 provides the best characterization of a future pension landscape in which DC plans are the dominant source of pension incomes. Because the benefits received from DC pension plans are so dependent on contribution rates and investment returns, we characterize each DC pension plan by the selfreported investment allocation and contribution rates in the SCF. ${ }^{6}$ Our main comparison will be

\footnotetext{
${ }^{4}$ Descriptions of the SCF 1983 are provided in Avery et al. (1984a, b).

${ }^{5}$ We impute plans to those respondents whose plans were not sampled in the PPS according to the methodology discussed in Appendix B.

${ }^{6}$ An alternative would be to use the actual DC plans reported in the 1989 PPS. We do not follow this approach for two reasons. First, this vintage of plans may not be sufficiently recent to accurately reflect DC pension plans at the end of the trend toward DC plans. Second, and more importantly, it is not clear that this PPS includes 401(k)
} 
between DB plans in the 1983 PPS and DC plans in the 1995 SCF.

The original documentation for the PPS in Curtin (1987) contains template programs that convert the PPS data into formulas to compute benefit entitlements under each plan. These original programs allow flexibility only in specifying economy-wide parameters for inflation, the interest rate, and productivity growth. As discussed in Appendix C, we have revised the original formulas based on Samwick (1993a, b) to allow for individual-specific investment allocations, stochastic wage profiles, and stochastic investment returns. These revisions allow us to compute pension entitlements accurately under a wide range of economic conditions for any observed or hypothetical worker.

\section{Simulation Methodology}

In this section, we present our methodology for characterizing the entire distribution of pension benefits from both DB and DC plans taking into account variation (for a given worker) in earnings and asset returns and variation (across workers) in the types of pension plans available. For DB plans, the annual benefit payment is typically specified in nominal terms and may change over time (such as providing an extra benefit in years before Social Security benefits are available). We therefore calculate the actuarial present value of the benefits and convert this actuarial present value into a constant, real annuity beginning at the age of retirement. ${ }^{7}$ For DC plans, we compute the constant, real annuity that could be supported by the balance in the account as of the retirement date. The real interest rate used in these calculations is 3 percent.

plans in its definition of DC plans. Given the widespread use of 401(k) plans as the sole source of employerprovided pension benefits, this is an important caveat.

\footnotetext{
${ }^{7}$ Allen, Clark, and McDermed (1992) report that firms accounting for 26 percent of workers gave ad hoc increases in pension benefits to account for inflation between 1983-1987. The probability of receiving such ad hoc adjustments is not reflected in our calculations. However, all pension plan formulas have been modified as in Samwick (1993a) so that dollar amounts specified in nominal terms are indexed to nominal wage growth.
} 
We specify pension benefits for worker i as $B_{i}=G_{i}\left(\tilde{y_{i}}, \tilde{r_{i}}, T\right)$. In this expression, $\mathrm{T}$ is the number of years of eligible service, $\tilde{y}_{i}$ is a $1 \mathrm{xT}$ vector of earnings for individual $\mathrm{i}$, and $\tilde{r}_{i}$ is a $1 \mathrm{xT}$ vector of returns that depends on the individual's portfolio allocation as well as the rates of return on the underlying assets. The function $\mathrm{G}_{\mathrm{i}}$ represents how the individual's pension plan maps earnings, rates of return, and years of service into the pension benefit. For ease of exposition, $\mathrm{G}_{\mathrm{i}}$ represents all of the plans for which a worker is eligible on his current job. In our sample, there are individuals with the same employer who are covered by the same pensions and multiemployer plans that cover workers from several different employers.

Clearly, both earnings and rates of return are stochastic, so each worker may face considerable uncertainty about his benefits at retirement. The probability that worker i receives retirement benefits from his pension plan that are less than a given level B is written:

$$
F_{i}(B)=\operatorname{Pr}\left\{G_{i}\left(\tilde{y_{i}}, \tilde{r_{i}}, T\right) \leq B\right\}
$$

where $\mathrm{F}_{\mathrm{i}}(\mathrm{B})$ is the probability of observing vectors $\tilde{y}_{i}$ and $\tilde{r}_{i}$ such that the resulting pension benefit is less than a given level $\mathrm{B}$.

The nature of our counterfactual experiment is to calculate pension benefits for each worker under two different pension scenarios. In the first scenario, workers are covered by their actual pension plans from the 1983 survey. In the second scenario, we take the same universe of workers (those with DB plans in 1983) and assign each a randomly chosen DC pension plan from the 1995 survey. In both scenarios, the realizations of earnings and asset returns are identical for each worker. Suppose that the new DC plan can be characterized by a new function $\mathrm{G}_{\mathrm{i}}^{*}$, with benefits equal to $B_{i}^{*}=G_{i}^{*}\left(\tilde{y}_{i}, \tilde{r}_{i}, T\right)$. We can also write the distribution function for this 
pension plan in a way similar to (1) above:

$$
F_{i}^{*}(B)=\operatorname{Pr}\left\{G_{i}^{*}\left(\tilde{y_{i}}, \tilde{r_{i}}, T\right) \leq B\right\}
$$

For a given worker, a comparison of these two distribution functions $\left(\mathrm{F}_{\mathrm{i}}\right.$ and $\left.\mathrm{F}_{\mathrm{i}}{ }^{*}\right)$ determines whether his real annuitized pension benefit is as large under the new DC plan as under the original 1983 plan. Since our objective is to compare the entire panoply of pension plans by vintage (DB plans in 1983 versus DC plans in 1995), we integrate over all plans in a given vintage to form an overall distribution function:

$$
F(B)=\sum_{i=1}^{N} \pi_{i} F_{i}(B)
$$

with a similar expression for $\mathrm{F}^{*}(\mathrm{~B})$, where the sample weight of observation $\mathrm{i}$ in our sample is given by $\pi_{i}$.

We compare the distributions $\mathrm{F}(\mathrm{B})$ and $\mathrm{F}^{*}(\mathrm{~B})$ in two ways. First, we can compute the expected value of pension benefits implied by each distribution:

$$
E(B)=\sum_{i=1}^{N} \pi_{i} E_{i}\left(G_{i}\left(\tilde{y}_{i}, \tilde{r}_{i}, T\right)\right)
$$

with a similar expression for $\mathrm{E}^{*}(\mathrm{~B})$. Second, we also compare the distributions at various percentiles. The following condition,

$$
F^{-1}(z)<F^{*-1}(z)
$$

implies that the benefit received at the $\mathrm{z}^{\text {th }}$ percentile from the $\mathrm{F}(\mathrm{B})$ distribution is lower than the benefit received at the same percentile from the $\mathrm{F}^{*}(\mathrm{~B})$ distribution. If the inequality holds, then $F^{*}(B)$ is preferred to $F(B)$ at the $z^{\text {th }}$ percentile.

Because we do not observe the entire history of earnings and asset returns, we proceed by making reasonable assumptions about the distribution of these variables. We assume that the 
structure of the earnings process is given by:

$$
\begin{aligned}
\ln \left(y_{i t}\right) & =X_{i t} \beta+u_{i t} \\
u_{i t} & =u_{i t-1}+\varepsilon_{i t} \\
\varepsilon_{i t} & \sim \text { i.i.d. } N\left(0, \sigma^{2}\right)
\end{aligned}
$$

where $\ln \left(y_{i t}\right)$ is the natural logarithm of earnings $y_{i t}$, which is assumed to follow a random walk with a quartic drift in age, represented by $\mathrm{X}_{\mathrm{it} .} \cdot{ }^{8}$ For computational simplicity, we ignore transitory shocks to earnings. ${ }^{9}$

The randomness in earnings is characterized by the T-1 vector of error terms $\left\{\varepsilon_{\mathrm{it}}\right\}$. Note that there are only $\mathrm{T}-1$ error terms because information from the cross-sectional survey provides us with earnings in one year. We project earnings forward using these error terms (i.e., given earnings in year $\mathrm{t}, \varepsilon_{\mathrm{it}+1}$ yields $\left.\mathrm{y}_{\mathrm{it}+1}\right)$. Because we do not have a complete wage history, we also project earnings back using analogous error terms (given earnings in year $\mathrm{t}, \boldsymbol{\varepsilon}_{\mathrm{it}}$ determines $\mathrm{y}_{\mathrm{it}-1}$, and successively back to $\varepsilon_{\mathrm{i} 2}$, which determines $\mathrm{y}_{\mathrm{i} 1}$ ).

Computing the expected pension benefits even for DB plans, which do not explicitly depend on interest rates, requires the evaluation of a T-1 dimensional integral over all of the shocks to earnings. Since the dimensionality corresponds to the years of service, it is not possible to evaluate this integral analytically. As an alternative, we simulate the probability distribution of earnings through simulated "draws" of T-1 independent values of $\varepsilon_{\mathrm{it}}$ from $\mathrm{N}\left(0, \sigma^{2}\right)$.

\footnotetext{
${ }^{8}$ The age-related components of earnings growth were estimated from the March 1983 Current Population Survey by regressing the logarithm of annual earnings on age, $\mathrm{age}^{2}, \mathrm{age}^{3}$, and $\mathrm{age}^{4}$ for full-time, white male workers. Murphy and Welch (1990) show that a quartic specification matches the empirical age pattern of earnings more accurately than the more typical quadratic specification using just age and $\mathrm{age}^{2}$, which tends to overstate the reduction or reversal of real wage growth near retirement.

${ }^{9}$ Omitting transitory shocks will make DB plans appear less risky than they actually are, as most of them calculate benefits based on a short average of earnings at the end of the working years where transitory shocks might play an important role. In contrast, under DC plans and a minority of DB plans, retirement income is based on a long average of earnings at the firm, so that transitory shocks will on balance have little effect on retirement income and their omission is inconsequential.
} 
Together with the actual reported earnings in the survey year, we can construct the worker's entire earnings history for each simulated draw. The worker is assumed fully employed during the entire $\mathrm{T}$ years, although we allow the worker to switch jobs or retire early in some of our simulations. For our basic analysis, we have the worker retire at age 65 . When we standardize the working career across workers to investigate the effects of turnover, we set $\mathrm{T}=35$, so the worker is employed from age 31 to 65 . We set $\sigma=0.10$ in equation (6) meaning that the standard deviation of the (permanent) innovation in log earnings is $0.10 .^{10}$ Economy-wide real earnings growth is assumed to be 1.5 percent annually, and the inflation rate is assumed to be 3 percent.

Estimating the benefits provided by DC plans also requires us to specify a process governing asset returns. The vector of returns $\tilde{r}_{i}$ over the $\mathrm{T}$ years depends on the portfolio of assets held and the rates of return on each asset. Suppose there are M different types of assets, with a $1 \mathrm{xM}$ vector of weights $\theta_{\mathrm{i}}$, which are assumed to be constant over time for a given worker. ${ }^{11}$ The $1 \mathrm{xT}$ vector of returns $\widetilde{r}_{i}$ is written as a weighted average of the asset-specific returns, $\widetilde{r}_{i}=\theta_{\mathrm{i}} \tilde{\rho}_{i}$. The MxT matrix of asset-specific returns $\tilde{\rho}_{i}$ is written (dropping the subscript i for legibility):

\footnotetext{
${ }^{10}$ Using a large sample of individual labor market histories taken from the Social Security earnings records of young men, Topel and Ward (1992) find that the evolution of wages within jobs closely approximates a random walk. They estimate the standard deviation of the permanent innovation in log earnings to be about 13 percent. Using similar methods but earnings histories of workers of all ages from the Panel Study of Income Dynamics, Samwick (1993a) also obtains an estimate of approximately 13 percent.

${ }^{11}$ Portfolio weights are estimated from the self-reported data on asset allocation of retirement accounts in the SCFs from 1989 (imputed to DC plans in 1983, when the SCF does not collect investment allocation data) and 1995. Constant portfolio weights imply that workers readjust their portfolios each year when rates of returns across assets differ.
} 


$$
\tilde{\rho}=\left[\begin{array}{ccc}
\tilde{\rho}_{1,1} & \cdots & \tilde{\rho}_{1, T} \\
\vdots & \ddots & \vdots \\
\tilde{\rho}_{M, 1} & \cdots & \tilde{\rho}_{M, T}
\end{array}\right]
$$

Rather than characterizing the structure of asset returns parametrically, we simulate $\widetilde{\rho}_{i}$ by using random draws of the actual returns received in years from 1901-1990. We follow Siegel (1992) and distinguish between three types of assets: short-term bonds, long-term bonds, and stocks $(M=3)$. A given worker will maintain the same asset weights throughout his life, and for all simulated draws from the sample of asset returns. As a working assumption, we assume that the asset returns and error terms from the wage distribution are uncorrelated. ${ }^{12}$

We require a sufficiently large number of simulated draws to provide an accurate characterization of the distribution functions $\mathrm{F}(\mathrm{B})$ and $\mathrm{F}^{*}(\mathrm{~B})$. One approach would be to sample each worker K times, and then use population weights provided in the SCF to weight the resulting distributions by $\pi_{i}$, the sample population weight from Equation (3). The main disadvantage of this approach is that it uses the same number of simulated draws for a worker with a small weight as for a worker with a very large weight.

Our approach is instead to set the number of simulation draws to be proportional to the sample weights, $\pi_{i}$. When these sample weights are summed over all households, they equal the total number of households in the U.S. population in a given year (or, for our subsample, the number of households with DB plans in 1983). The number of draws chosen is written $\mathrm{K}_{\mathrm{i}}=$ integer $\left\{\mathrm{p}^{*} \pi_{\mathrm{i}}\right\}$, where $\mathrm{p}$ is our overall sampling frequency. For example, if $\mathrm{p}=1 / 1000$ and individual i's population weight $\pi_{\mathrm{i}}=25,000$, we simulate 25 different earnings and asset

\footnotetext{
${ }^{12}$ We do not allow for serial correlation in the asset returns, so that the years of historical returns are assumed to be i.i.d. We have tested for the robustness of our results to this assumption by also sampling asset returns in fiveyear "blocks" with replacement, so it would be possible for a single individual to sample the years (say) 1929-33 and then 1930-34. The results were similar to those reported below.
} 
"histories," and hence generate 25 different realizations of pension benefits for this particular worker.

\section{Empirical Results}

In the 4,103 households in the $1983 \mathrm{SCF}$, there are 1,489 workers who report being covered by a pension at their current employers and whose plans (up to four per worker) are found in the PPS. Because many individuals may participate in the same plan, the total number of different plans used is 928 . There are an additional 221 workers who report being covered only by a thrift plan, which were not included in the PPS. We code thrift plans as pensions that simply accumulate employee and employer contributions. There are also 552 workers who report coverage in a pension plan but whose plans are not found in the PPS. These workers were assigned a pension plan according to the imputation procedure described in Appendix B. Using sample weights, there are 44.85 million workers covered by pensions. Our 1/1000 sampling rate yields a total of 46,045 sample observations (the discrepancy is due to rounding error and needing at least one sample observation for respondents with sample weights less than 1000). ${ }^{13}$ Increasing the sampling rate to $1 / 100$ did not affect our results.

Sample means for individual characteristics relevant for computing expected pension benefits are given in the first column of numbers in Table 1. The average worker covered by a pension in 1983 was 42 years old and was earning $\$ 23,600$ annually (in 1983 dollars) after an average of 11 years on the job. Workers who made voluntary contributions to DC pension plans (i.e., those who would be represented in the PPS) gave an average of 5.56 percent of their earnings. Workers covered by thrift plans (i.e., those not represented in the PPS) contributed approximately 4 percent of earnings, as did their employers. In our simulations that investigate

\footnotetext{
${ }^{13}$ Tabulations of coverage among full-time workers using the May 1983 Current Population Survey suggest a range of 40.28-44.76 million workers in pensions (see Congressional Budget Office, 1987).
} 
the effects of job turnover, we standardize the characteristics of the workers to reflect these average characteristics, as shown in the second column of the table. The use of this benchmark "representative agent" also allows us to control for the impact of worker heterogeneity on pension variation and return.

Information on the investment allocation of DC plans was not collected in the SCF 1983. In subsequent surveys, respondents were asked about the allocations in the largest three of up to four accounts. The respondents could indicate whether the account was invested "mostly or all in stock," "mostly or all in interest earning assets," or "split between these." ${ }^{14}$ We assigned shares of stocks equal to 100,0 , and 50 percent, respectively, for these responses. We randomly assign allocations from the SCF 1989 to respondents in the SCF 1983 and use the allocations reported in the SCF 1995 for the sample of matched DC plans. The reported allocations in stock for these two years are presented in Table 2. The share in stocks increased substantially between the two years, suggesting a more aggressive investing strategy in 1995.

As discussed above, we use the sample of returns on stocks, short-term corporate bonds, and long-term corporate bonds for the 1901-1990 period from Siegel (1992) to simulate the stochastic returns on DC accounts. Summary statistics for the real returns are presented in Table 3. The first row of the table shows that stocks had an average annual real return of 7.95 percent per year, compared to 1.58 percent for long-term bonds and 0.75 percent for short-term bonds. The remainder of the table presents other summary statistics on the distribution of returns, including the correlation matrix. Stocks clearly provide the highest average returns and the most risky returns. ${ }^{15}$ In our imputations of investment allocations, we assume that all "interest-

\footnotetext{
${ }^{14}$ The proceeds of the fourth account were assumed to be invested in the same proportions as the other three in our simulations. All miscellaneous investment allocations were classified as "interest bearing."

${ }^{15}$ We may understate total asset variability to the extent that DC plan enrollees sink a large fraction of their
} 
bearing" assets are evenly divided between short-term and long-term bonds. We also assume constant portfolio shares, implying an annual rebalancing of pension accounts.

Our main source of comparisons will be between the pension benefits that could be expected from the 1983 vintage of plans and the benefits that could be expected from the 1995 vintage of DC plans. We assign each 1983 worker a randomly chosen DC plan from the SCF 1995. Each "plan" from 1995 includes the investment allocation discussed above and the reported employee and employer contributions. We restrict our attention to DC plans described by respondents as involving "tax-deferred savings accounts," such as 401(k) and other thrift plans.

Approximately 27.8 percent of the workers in the SCF 1995 were covered by such a DC plan, up from 18.0 percent in the 1989 SCF. Although the sampling frames are slightly different, these coverage rates are consistent with those from the CPS for the 1988 and 1993. (We present a full comparison of the two surveys in Appendix A.) In 1995, 78.8 percent of the covered workers made a contribution to their plans. The average employee contribution rate (including those who did not contribute) was 5.3 percent of earnings, and the average dollar contribution was $\$ 2,502$. The average percent contributed by employers was 5.0 with an average dollar value of $\$ 2,160$.

The results of our counterfactual simulations are presented in Table 4. The top panel presents the mean, median, $10^{\text {th }}$ percentile, $90^{\text {th }}$ percentile, and standard deviation of pension benefits for actual workers in the SCF 1983 assuming they continue working on their current jobs until age 65. The workers covered only by DB plans only can expect an average of $\$ 10,553$ in retirement benefits if they continue to work until age 65 . If these same workers with identical

pension fund in just one or two stocks or bonds, rather than the market averages as we are assuming. 
earnings histories are given randomly chosen DC plans, their expected pension benefits are $\$ 25,275$. (All values are in 1983 dollars. Multiply by 1.61 for 1997 dollars.) The disparity is less severe at the medians, with the worker receiving $\$ 7,214$ and $\$ 10,841$ under the DB and DC plans, respectively. A comparison of the means and medians suggests a more skewed distribution of DC benefits in the upper tail, which is borne out in a comparison of the $90^{\text {th }}$ percentiles ( $\$ 58,415$ for DC versus $\$ 23,150$ for DB). At the $10^{\text {th }}$ percentile of the distribution, benefits are higher under the DB plans ( $\$ 1,162$ for DC versus $\$ 1,461$ for DB). ${ }^{16}$ Figure 1 shows the full distribution function for the DB and DC plans. Note that DB plans dominate DC plans in the bottom quintile of the distribution, but the difference is only $\$ 299$ annually at the $10^{\text {th }}$ percentile.

The remaining columns of Table 4 examine the sensitivity of our results. One possibility is that future stock market returns will not be as high as those from $1900-1990$. Column 3 compares the returns to the $1995 \mathrm{DC}$ plans when the rate of return on equity is reduced by 3 percent, from an average of 7.95 to 4.95 percent. (Given the share of bonds and stocks in 1995, this translates to a return averaged over all workers of 3.5 percent.) While DC pension benefits are not so generous under this scenario, the mean $(\$ 15,751)$ and median $(\$ 7,943)$ still exceed those for the DB plan. Another possibility is that our earnings uncertainty is too high. Columns 4 and 5 consider the case where uncertainty in earnings innovations is lowered to a log standard error of 0.05. While the median DB pension is somewhat higher, the median DC pension is also

\footnotetext{
${ }^{16}$ Our omission of Social Security benefits from the distribution of pension benefits has two effects on the comparisons of income distributions. First, in 1983, some public sector workers are not covered by Social Security. Their DB plans are designed to provide a replacement rate comparable to the combined Social Security and pension benefits of a private sector worker. This leads to an upward bias in the estimated DB benefits at the mean and higher percentiles. Second, among private sector plans, many are explicitly integrated with Social Security such that higher Social Security benefits are offset by lower pension benefits. Omitting Social Security from the retirement income would overstate the riskiness of these offset plans. Since DB plans are found to have both lower average benefits and lower variability of benefits, the omission does not change the qualitative comparisons that we make.
} 
higher. The degree of earnings uncertainty does not appear to be a crucial issue for these comparisons. Finally, Columns 6 and 7 show the comparisons when productivity growth is assumed to be 2.5 percent annually. A higher productivity growth gives a greater edge to DB plans, since benefits are typically tied to the last few years of earnings. However, pension benefits are still substantially larger for DC plans, although the difference in benefits at the bottom of the distribution (\$1,651 for DB plans and $\$ 1,199$ for DC plans) are more pronounced.

Some of the DB plans from 1983 included supplemental DC plans. In separate simulations, we included these hybrid DB/DC plans in the universe of DB plans and performed the same counterfactual as in Table 4 by giving them randomly chosen DC plans from 1995. The combination DB/DC plans, which comprise about one-fourth of all DB plans, tended to be more generous than straight DB plans in 1983, so the median and mean benefits are higher, $\$ 8,889$ and $\$ 15,499$. However, because those receiving these plans also were better compensated than the average DB employee was, benefits for this group under a matched DC plan were also higher, with median and means of $\$ 11,743$ and $\$ 27,254$. Like the results in Table 4 , the $90^{\text {th }}$ percentile for DC plans were substantially higher $(\$ 62,362$ versus $\$ 33,418)$ and the $10^{\text {th }}$ percentile slightly lower $(\$ 1,410$ versus $\$ 1,784)$.

Our assumption above that people work full time until age 65 is clearly an oversimplification. Table 5 shows how allowing for early retirement or later starting ages of pension coverage affects pension benefits. To address these issues, we want to abstract from differences across individuals in their age cohort and lifetime earnings. Instead, we use a single benchmark or representative worker who was age 42 in 1983 and earned $\$ 23,600$. Other parameters are as shown in the second column of Table 1. Thus, all variation in retirement benefits is the consequence of heterogeneous pension plans, contribution rates, and investment 
allocations from the SCF and PPS and random earnings and asset returns for each observation. Columns 1 and 2 present the distribution of pension benefits for the standard case where the representative individual works from 31 to 65 . The difference between the standard deviation of DB pension plan benefits in Column 1 of Table $5(\$ 8,254)$ and the standard deviation in Column 1 of Table $5(\$ 10,994)$ is that the latter distribution also reflects the cross-sectional variation in 1983 earnings for the universe of workers with DB plans. Note that for the benchmark worker in Table 5, DC plans dominate DB plans even at the $10^{\text {th }}$ percentile.

Because the benchmark comparisons focus on a single worker, we can make expected utility comparisons between the distributions of DB and DC plan benefits. Using a constant relative risk aversion expected utility function, we computed the expected utility of each distribution under the assumption that the worker had income only from Social Security benefits (based on the same random earnings draws that generate the pension benefits) for a single retiree and the pension benefit. The expected utility of the distribution from the DC plans dominated utility from the DB plans for all values of relative risk aversion up to and including 12. An alternative comparison is to compute the percentage increase in DB benefits that would have to be applied to the entire distribution that would leave the worker indifferent between the two distributions. For coefficients of relative risk aversion of 3 and 5, these percentages were 67 percent and 52 percent, respectively. In other words, for a typical worker with reasonable amounts of risk aversion, the shift from DB to DC pensions has resulted in an increase in expected utility equal to a one-half to two-thirds increase in pension benefits. ${ }^{17}$

Columns 3 and 4 in Table 5 show the effects of early retirement at age 55 on the

\footnotetext{
${ }^{17}$ A similar exercise can be performed for the counterfactual exercise shown in Table 4 and Figure 1. In this case DC plans are preferred to DB plans for relative risk aversion measures up to 5. But it is not clear that these distributions can be compared in a utility framework, given that the "uncertainty" in retirement outcomes reflects in part heterogeneity among workers.
} 
comparisons between DB and DC plans. Early retirement (or movement into "bridge jobs") is in fact encouraged by the early retirement incentives in DB pension plans (Kotlikoff and Wise, 1987). Pension benefits are lower in all cases, but the overall comparisons across plan types remain the same. Some DB plans provide little incentive to retire at age 55, which explains why the $10^{\text {th }}$ percentile benefits $(\$ 897)$ are so much lower than those for DC plans $(\$ 1,637)$. We also consider what happens if workers do not make retirement saving a priority until late or midway through their careers. Like the previous results, DC plans generally dominate DB plans for jobs that start at age 42 with retirement at age 65 , shown in Columns 5 and 6 of Table 5. But for jobs beginning at age 53 and ending at age 65 , where the differences between the two types of pensions are less pronounced (Columns 7 and 8), DC plans still tend to dominate DB plans. Lastly, we address the issue of how job turnover affects the accumulation of pension benefits at retirement. Two considerations are important in this regard. First, because DB pensions are backloaded — providing greater marginal rewards for another year of service at higher tenures-they penalize early turnover substantially. Second, workers often do not roll over their DC balances from previous jobs into similar tax-preferred saving vehicles when they change jobs. A recent EBRI (1997) study reported that only 42 percent of workers rolled all or part of their lump sum distribution into an IRA, with another 8 percent moving their assets into their new employer's plan. Workers who spend their lump-sum disbursements could therefore experience a marked attenuation in their retirement income.

To assess the importance of this leakage, we consider two scenarios in Table 6. In the first, workers start work at age 31 and quit that job at age 42 . By working 11 years, they will almost always have earned some vested benefits under a DB plans, since the most prominent vesting schedule was full vesting after 10 years of service. In the second, employees start work 
at age 42 and work until age 53. For both scenarios, we characterize the distribution of pension wealth at the job transition. This represents the actuarial present value of vested benefits for DB plans and the balance in the account for DC plans.

The first thing to note is that short job spells at younger ages typically generate low benefits from DB plans. The comparisons to DC plans are less favorable than in the earlier scenarios in which the worker stayed through age 55 or 65 . At ages 31 to 42 (Columns 1 through 3), mean DB wealth is only 26 percent of mean DC wealth; the ratio of medians is even lower. Looking at the job from ages 42 to 53 (Columns 4 through 6), mean DB wealth is still just 46 percent of DC wealth. In order to maintain parity with the DB plans, workers need only save one-fourth of distributions received early in their careers and one-half of distributions received later in their careers.

Poterba, Venti, and Wise (1998) report that the probability of reinvesting lump-sum distributions based on the 1993 CPS rises steadily with age and is 48 percent for those age 35 to 44, 57 percent for those age 45 to 54 , and 73 percent for those age 55 to 64 . While this is a somewhat different calculation than the fraction of each distribution that is reinvested, the figures are substantially above the amounts that we calculate are necessary to match what was offered to short tenure workers by traditional DB plans. And this comparison considers only the effect of the distributions on future retirement income-it does not account for the workers benefiting from actually spending that money or using it to pay off mortgages, rather than having it revert to employers under DB plans.

\section{Are Workers Really Better Off Under DC Plans?}

One important limitation of our analysis is that we focus just on retirement benefits and not on the general equilibrium wage and saving effects that could occur as DC plans cover a 
larger fraction of workers. Standard economic theory would suggest that, tax issues aside, the form of the pension program is irrelevant to the worker's retirement security. What matters is the total compensation package of the worker, which includes both wages and fringe benefits. Any changes in the magnitude and risk characteristics of the pension plan can be neutralized by the appropriate adjustment to net wages and the non-pension wealth of the worker. For example, a shift from a DB plan funded by the employer to a DC plan funded entirely by employee contributions has a first-order impact on the overall wage of the worker. To keep compensation constant, employers increase the gross wage by the amount they had previously contributed to the DB pension fund. In this case, the bias goes against DC plans, since increasing gross earnings in the DC counterfactual would also increase simulated DC benefits.

Suppose, however, that firms understood that DC plans provided generally superior benefits to employees at retirement. In this case, firms could respond by reducing wages while keeping the overall compensation package the same. But for this effect to dominate the opposite bias noted above, it would have to be the case that DB plans yield lower retirement benefits than the DC plans counting only employer contributions. ${ }^{18}$ Simulations (not reported) suggest the opposite; the reason why DC plans generally dominate DB plans is because of the additional employee contribution. Thus, we argue that at least for these general equilibrium effects, the net effect is to bias downward our estimated net pension benefits for DC plans.

Another possibility is that the expansion of DC plans has been associated with a general downward trend in the generosity of employer-provided pensions. Thus, DC pension benefits in the future could be worse than projected based on 1995 survey data. To test for this trend, we first simulated pension benefits for the universe of people with DC plans in the $1983 \mathrm{SCF}$. We

\footnotetext{
${ }^{18}$ The employer can cut wages in the DC world only if the employer contribution to the DC plan yields higher benefits than the status quo DB plan. Otherwise the worker would be worse off.
} 
then took those same people, with identical earnings and asset return realizations, and gave them random 1995 DC plans. Median benefits for 1983 DC plans were $\$ 8,000$, compared to $\$ 12,079$ for 1995 DC plans. Similarly, both the mean $(\$ 19,443$ versus $\$ 28,948)$ and the $10^{\text {th }}$ percentile (\$780 and \$1,297) were higher for the 1995 plans. In short, characteristics of plans available in 1995 appear to offer better retirement benefits than plans in 1983.

It could also be the case that workers are simply saving less in non-pension form as a response to the increased employee contributions. For example, suppose a worker in a 1983 DB plan was saving an additional 10 percent of earnings for retirement. By 1995, the worker no longer has a DB plan, but contributes 5 percent to her $401(\mathrm{k})$ and is saving 5 percent. In this case, there is a complete offset between taxable saving and tax-deferred saving, suggesting no better financial security (aside from a tax break) despite the higher apparent retirement pension balances.

Unfortunately, this story - that workers with pensions are no better prepared for their retirement than they were in 1983 - is difficult to evaluate with the available data, given other changes in the economic environment since then. (A simpler question, whether workers with 401(k) accounts reduce their non-pension saving as a consequence, is still mired in debate. ${ }^{19}$ ) Thus, we must limit our question (and answer) to one that compares actual retirement benefits under a DB regime and those under a DC regime.

\section{Conclusion}

The surprisingly rapid increase in the number of defined contribution pension plans raises an obvious question: will such plans provide adequate retirement income security compared to the previously dominant defined benefit plans? We have addressed this question using a large

\footnotetext{
${ }^{19}$ For example, see Engen, Gale, and Scholz (1996), Poterba, Venti, and Wise (1996), and Hubbard and Skinner (1996).
} 
sample of workers and detailed information on their pension plans from the Surveys of Consumer Finances from 1983 and 1995. Our results suggest that the typical DC plan in 1995 does a better job on average of providing for retirement pension benefits than the typical DB plan from 1983.

This result is robust to a number of specifications. For example, some workers spend their lump-sum distributions from DC plans when they switch jobs. While spending down such plans reduces retirement income, we show that workers can spend 50 percent of their DC plan assets when they switch jobs and still enjoy a nearly equivalent retirement income as under the DB plan regime. Furthermore, employees under DC plans get to spend their pension benefits, while employees under DB plans simply forego most of their potential benefits.

What about workers who neglect to contribute to $401(\mathrm{k})$ plans altogether? It is true that a large number of workers fail to contribute to their $401(\mathrm{k})$ plans. However, the ones who fail to contribute typically have an alternative plan, such as a DB pension; the 401(k) is simply a supplemental plan. In Samwick and Skinner (1997), we estimated that only 2-4 percent of all workers are offered 401(k) plans to which they fail to contribute and have no alternative pension plan.

Defined contribution plans appear to expose workers to more risk from stock and bond rates of return. But because the mean is also higher, the distribution of pension benefits under 1995 DC plans is generally preferred to the distribution of pension benefits under 1983 DB plans. Nevertheless, DC plans do slightly worse than DB plans for the bottom 20 percent of retirement pension benefits, on the order of $\$ 300$ annually at the $10^{\text {th }}$ percentile. Still, when we consider the case of a benchmark worker, the distribution of DC benefits are preferred to the distribution of DB benefits for a measure of relative risk aversion as high as 12 .

One limitation of our study is that we have not conducted multi-dimensional sensitivity 
analysis. For example, suppose that the rate of return on stocks is lower than historical returns, and individuals increase borrowing against or spending down their $401(\mathrm{k})$ balances. Then more current employees could find themselves worse off than under the older style DB plan. ${ }^{20}$ Another limitation is that we have not addressed the difference in how pension benefits are paid out; DB plan benefits are often provided as annuities, while DC plan benefits are typically lumpsum payments to retirees. Nevertheless, our results suggest that the trend toward defined contribution plans has strengthened, not eroded, the retirement security of future retirees.

\footnotetext{
${ }^{20}$ This assumes, of course, that the firm can meet its DB obligations, which would become questionable if asset returns fell significantly.
} 


\section{References}

Allen, Steven G.; Clark, Robert L.; and McDermed, Ann A. "Post-Retirement Benefits Increases in the 1980s." In Trends in Pensions 1992, edited by John A. Turner and Daniel J. Beller. Washington: U.S. Department of Labor, 1992.

Avery, Robert B.; Elliehausen, Gregory E.; Canner, Gregory; and Gustafson, Thomas. "Survey of Consumer Finances, 1983.” Federal Reserve Bulletin 70 (September 1984): 679-692. (a)

Avery, Robert B.; Elliehausen, Gregory E.; Canner, Gregory; and Gustafson, Thomas. "Survey of Consumer Finances, 1983: A Second Report." Federal Reserve Bulletin 70 (December 1984): 857-868. (b)

Beller, Daniel J., and Lawrence, Helen H. “Trends in Private Pension Plan Coverage.” In Trends in Pensions 1992, edited by John A. Turner and Daniel J. Beller. Washington: U.S. Department of Labor, 1992.

Bodie, Zvi; Marcus, Alan J.; and Merton, Robert C. "Defined Benefit versus Defined Contribution Pension Plans: What are the Real Trade-offs?" In Pensions in the U.S. Economy, edited by Zvi Bodie, John B. Shoven, and David A. Wise. Chicago: University of Chicago Press, 1988.

Congressional Budget Office. Tax Policy for Pensions and Other Retirement Saving. Washington: United States Government Printing Office, April 1987.

Crenshaw, Albert B. "Borrowing From Your 401(k): When to Leave a Loan Alone." The Washington Post. November 23, 1997, Section H, p. 1.

Curtin, Richard T. Survey of Consumer Finances Employer Sponsored Pension Benefit Plans: Documentation and Codebooks. Ann Arbor, MI: Survey Research Center, University of Michigan, 1987.

Dow Jones News Service. "Government May Join Employer Trend Toward 401(k) Retirement Plans; But Shift Away from Traditional Pensions Raises Concerns and Worries Some People." The Minneapolis Star Tribune. December 12, 1995, Section D, p. 2.

Employee Benefit Research Institute (EBRI). "Employment-Based Retirement Income Benefits." Special Report SR-25 and Issue Brief Number 153. Washington: September, 1994.

Employee Benefit Research Institute (EBRI). Fundamentals of Employee Benefit Programs. Washington: 1997.

Engen, Eric M.; Gale, William G.; and Scholz, J. Karl. “The Illusory Effects of Saving Incentives on Saving." Journal of Economic Perspectives 10 (Fall 1996): 113-138.

Ferguson, Karen, and Kate Blackwell. Pensions in Crisis. New York: Arcade Publishing, 1995. 
Flaherty, Francis. "Employee Pension Plans Can Suffer From Neglect." The New York Times. November 13, 1993, Section 1, p. 37.

Flavelle, Dana. "Defined Contribution Pensions Gain Favour: Transfer More Risk and Reward to Employees.” The Toronto Star. October 25, 1997, Section C, p. 4.

Gustman, Alan L., and Steinmeier, Thomas L. "A Structural Retirement Model." Econometrica 54 (1986): 555-584.

Gustman, Alan L., and Steinmeier, Thomas L. "An Analysis of Pension Benefit Formulas, Pension Wealth, and Incentives for Retirement." in R. Ehrenberg (ed.) Research in Labor Economics 10. Greenwich, CT: JAI Press, 1989.

Hubbard, R. Glenn and Skinner, Jonathan S. "Assessing the Effectiveness of Saving Incentives." Journal of Economic Perspectives 10 (Fall 1996): 73-90.

Kotlikoff, Laurence J., and Smith, Daniel E. Pensions in the American Economy. Chicago: University of Chicago Press, 1983.

Kotlikoff, Laurence J., and Wise, David A. "The Incentive Effects of Private Pension Plans." In Issues in Pension Economics, edited by Zvi Bodie, John B. Shoven, and David A. Wise.

Chicago: University of Chicago Press, 1987.

Martinson, Jane. "Uncertainty Prompts Pension Payout Fears." The Financial Times. February 13, 1998, p. 9.

McGill, Dan M.; Brown, Kyle N.; Haley, John J.; and Schieber, Slyvester J. Fundamentals of Private Pensions. Seventh Edition. Philadelphia: University of Pennsylvania Press.

Murphy, Kevin M., and Welch, Finis. “Empirical Age-Earnings Profiles.” Journal of Labor Economics 8 (April 1990): 202-229.

Olsen, Kelly and VanDerhei, Jack. "Defined Contribution Plan Dominance Grows Across Sectors and Employer Sizes, While Mega Defined Benefit Plans Remain Strong: Where We Are and Where We Are Going." Employee Benefit Research Institute Special Report SR-33 and Issue Brief Number 190. Washington: October, 1997.

Papke, Leslie, "Are 401(k) Plans Replacing Other Employer-Provided Pensions? Evidence from Panel Data," mimeo, Michigan State University (October 1997).

Poterba, James M.; Venti, Steven F.; and Wise, David A. "How Retirement Saving Programs Increase Saving." Journal of Economic Perspectives 10 (Fall 1996): 91-112.

Poterba, James M.; Venti, Steven F.; and Wise, David A. "Lump-Sum Distributions from Retirement Savings Plans: Receipt and Utilization." in David A. Wise (ed.) Inquiries in the 
Economics of Aging. Chicago: University of Chicago Press, 1998, 85-105.

Samwick, Andrew A. "Wage Risk Compensation Through Employer-Provided Pensions." Manuscript. Cambridge, MA: Massachusetts Institute of Technology, April 1993. (a)

Samwick, Andrew A. "The Effect of Tax Reform Act of 1986 on Pension Coverage: Evidence from Pension Provider Surveys.” Manuscript. Cambridge, MA: National Bureau of Economic Research, July 1993. (b)

Samwick, Andrew A. "New Evidence on Pensions, Social Security, and the Timing of Retirement." National Bureau of Economic Research, Working Paper No. 6534, April 1998. Forthcoming in Journal of Public Economics.

Samwick, Andrew A., and Jonathan Skinner. "Abandoning the Nest Egg? 401(k) Plans and Inadequate Pension Saving." in Sylvester J. Schieber and John B. Shoven (eds.) Public Policy Toward Pensions. Cambridge: MIT Press, 1997, 197-217.

Schultz, Ellen E. "Your Money Matters: Raiding Pension Money Now May Leave You Without a Piggy Bank for Retirement.” The Wall Street Journal. April 7, 1993, Section C, p. 1.

Siegel, Jeremy J. "The Real Rate of Interest from 1800-1990: A Study of the U.S. and U.K." Journal of Monetary Economics 29 (April 1992): 227-252.

Stock, James H., and Wise, David A. "Pensions, the Option Value of Work, and Retirement." Econometrica 58 (October 1990): 1151-1180.

Topel, Robert H., and Ward, Michael P. "Job Mobility and the Careers of Young Men." Quarterly Journal of Economics 107 (May 1992): 439-479.

Willette, Anne. "Saving Your Retirement: Few Workers Know Risks of 401(k) Plans." USA Today. February 20, 1995, Section A, p. 1.

Woodbury, Richard. "The Motivations for Business Retirement Policies." Manuscript, National Bureau of Economic Research, May 1997. 
Figure 1

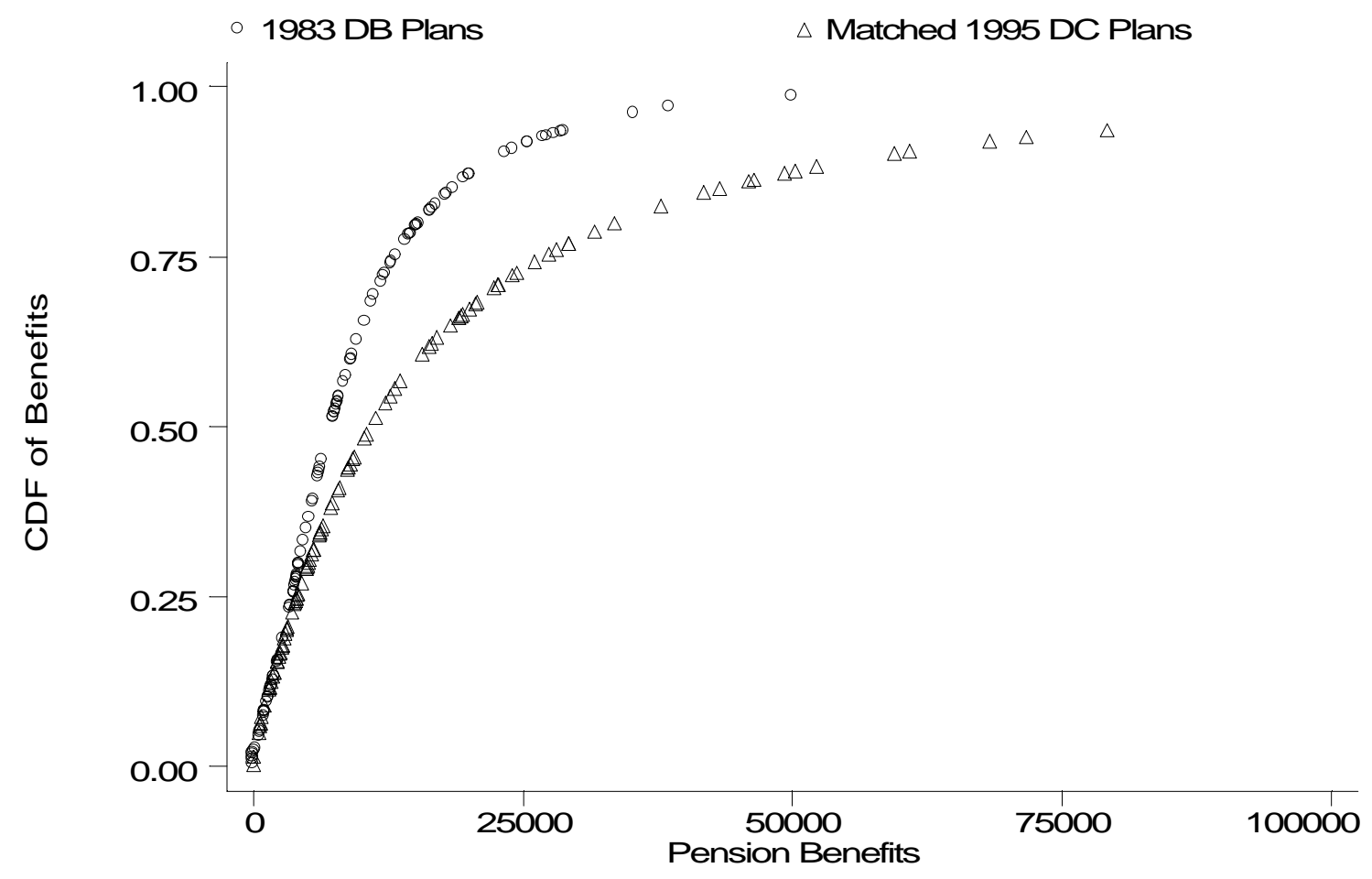


Table 1

Characteristics of Covered Population in the SCF 1983

\begin{tabular}{lcc}
\hline Characteristic & Sample Average & Benchmark Worker \\
\hline Date of Birth & 1941.66 & 1941.50 \\
Date of Hire & 1972.74 & 1972.50 \\
Annual Earnings (1983 \$) & 23584.03 & 23600.00 \\
Annual Hours of Work & 2058.91 & 2080.00 \\
Percent Female & 39.53 & 0.00 \\
Contributions to Thrift Plans & & 4.00 \\
Employee (percent) & & 4.00 \\
Employer (percent) & 3.96 & 5.00 \\
Voluntary Contributions to & 4.07 & \\
DC Plans (if positive) & 5.56 & \\
\end{tabular}

Notes:

1) Source: Authors' calculations from the Survey of Consumer Finances, 1983.

2) All statistics reflect the weighted sample of households covered by a pension or thrift plan and include households for which pension plans were imputed. 
Table 2

Share of Retirement Accounts in Equity in SCFs 1989 and 1995

\begin{tabular}{l|c|c}
\hline \hline & 1995 & 1989 \\
\hline & & \\
None & 17.47 & 33.19 \\
Under 50 percent & 1.52 & 3.45 \\
Exactly 50 percent & 41.06 & 35.70 \\
Over 50 percent & 4.33 & 1.08 \\
All & 35.62 & 26.58 \\
\hline \hline
\end{tabular}

Notes:

1) Responses are tabulated for the question in the SCF: "How is the money in this account invested? Is it mostly in stocks, mostly in interest earning assets, is it split between these, or what?" Possible answers are:

a) Mostly or all stock; stock in company

b) Mostly or all interest earning; guaranteed; cash; bank account

c) Split between stock and interest earning assets

d) Real estate

e) Insurance / Retirement plan

f) Other

2) Responses (a) and (c) are imputed at 100 and 50 percent, respectively. All other responses are imputed at 0 percent. Intermediate values may occur if respondents have more than one account and invest them differently.

3) The SCF 1995 is used for the matched sample of DC plans. The SCF 1989 is used for the sample of 1983 DC plans. 
Table 3

Descriptive Statistics on Real Asset Returns, 1901-1990

\begin{tabular}{l|c|c|c}
\hline \hline & Short-Term Bonds & Long-Term Bonds & Stocks \\
\hline Mean & 0.75 & 1.58 & 7.95 \\
Standard Deviation & 4.88 & 9.35 & 20.62 \\
Maximum & 17.38 & 35.12 & 75.59 \\
90th Percentile & 2.99 & 6.60 & 21.12 \\
Median & 1.25 & 1.01 & 8.99 \\
10th Percentile & -1.23 & -4.51 & -6.12 \\
Minimum & -15.07 & -16.74 & -42.64 \\
Correlation with: & 1.00 & & \\
Short-Term Bonds & 0.66 & 1.00 & 1.00 \\
Long-Term Bonds & 0.17 & 0.32 & \\
Stocks & & & \\
\hline \hline
\end{tabular}

Notes:

1) Source: Authors' tabulations based on Siegel (1992).

2) All returns reflect the real holding period returns on the market portfolio of each type of security: short-term corporate bonds, long-term corporate bonds, and corporate equities. 
Table 4

Pension Benefit Distributions for DB plan, Counterfactual Case

\begin{tabular}{|c|c|c|c|c|c|c|c|}
\hline & & ine Assum & & Uncertainty & wered to $5 \%$ & Productivity I & eased to $2.5 \%$ \\
\hline & 1983 DB Only & $\mathrm{M}$ & d DC & 1983 DB Only & Matched DC & 1983 DB Only & Matched DC \\
\hline Asset Returns & & Historical & Equity $-3 \%$ & & Historical & & Historical \\
\hline Mean & 10,553 & 25,275 & 15,751 & 10,330 & 25,389 & 13,106 & 26,370 \\
\hline Median & 7,214 & 10,841 & 7,943 & 7,681 & 11,208 & 8,768 & 11,403 \\
\hline $10^{\text {th }}$ Percentile & 1,461 & 1,162 & 966 & 1,618 & 1,200 & 1,651 & 1,199 \\
\hline $90^{\text {th }}$ Percentile & 23,150 & 58,415 & 36,493 & 22,218 & 58,667 & 29,859 & 61,482 \\
\hline Std. Deviation & 10,994 & 52,254 & 26,171 & 9,414 & 51,745 & 13,706 & 53,159 \\
\hline
\end{tabular}

\section{Notes:}

1) All amounts are in 1983 dollars (CPI97/CPI83 = 1.61) and represent the level of constant, real annuities payable at retirement based on the actuarial present value of DB pension benefits or the balance in the DC pension account.

2) The left column in each panel is the distribution of pension benefits from the actual sample of plans covering the SCF 1983 sample respondents. The right column is the distribution of pension benefits from the matched sample of 1995 DC plans.

3) The 1983 sample of 46,045 observations is 60.2 percent DB plan only, 17.4 percent DC only, and 22.4 percent with a combination of DB and DC plans.

4) The baseline assumptions assume a $10 \%$ standard deviation of the permanent shock to earnings each year, a $1.5 \%$ rate of annual productivity growth, and a retirement age of 65 . 
Table 5

Pension Benefit Distributions for Different Careers, Benchmark Case

\begin{tabular}{|c|c|c|c|c|c|c|c|c|}
\hline & \multicolumn{2}{|c|}{ Full Career: Age 31 to 65} & \multicolumn{2}{|c|}{ Retire Early: Age 31 to 55} & \multicolumn{2}{|c|}{ Start at $42:$ Age 42 to 65} & \multicolumn{2}{|c|}{ Start at 53: Age 53 to 65} \\
\hline & $1983 \mathrm{DB}$ & Matched DC & $1983 \mathrm{DB}$ & Matched DC & $1983 \mathrm{DB}$ & Matched DC & $1983 \mathrm{DB}$ & Matched DC \\
\hline Mean & 11,273 & 24,068 & 4,333 & 8,352 & 7,818 & 12,382 & 4,044 & 4,843 \\
\hline Median & 8,848 & 15,184 & 3,562 & 6,020 & 6,179 & 8,689 & 3,202 & 3,545 \\
\hline $10^{\text {th }}$ Percentile & 3,416 & 3,702 & 897 & 1,637 & 2,518 & 2,315 & 1,157 & 995 \\
\hline $90^{\text {th }}$ Percentile & 21,609 & 52,363 & 8,528 & 17,448 & 14,823 & 26,495 & 7,627 & 10,264 \\
\hline Std. Deviation & 8,254 & 30,695 & 3,583 & 8,319 & 5,687 & 12,834 & 3,142 & 4,478 \\
\hline
\end{tabular}

\section{Notes:}

1) All amounts are in 1983 dollars (CPI97/CPI83 = 1.61) and represent the level of constant, real annuities payable at retirement based on the actuarial present value of DB pension benefits or the balance in the DC pension account.

2) The left column in each panel is the distribution of pension benefits from the actual sample of plans covering the SCF 1983 sample respondents. The right column is the distribution of pension benefits from the matched sample of 1995 DC plans.

3) The 1983 sample of 46,045 observations is 60.2 percent DB plan only, 17.4 percent DC only, and 22.4 percent with a combination of DB and DC plans.

4) The baseline assumptions assume a $10 \%$ standard deviation of the permanent shock to earnings each year, a $1.5 \%$ rate of annual productivity growth, and historical rates of return on assets. 
Table 6

Pension Wealth at Turnover Before Retirement, Benchmark Case

\begin{tabular}{|c|c|c|c|c|c|c|}
\hline & \multicolumn{3}{|c|}{ Early Career Job: Age 31 to 42} & \multicolumn{3}{|c|}{ Middle Career Job: Age 42 to 53} \\
\hline & 1983 DB Only & Matched DC & $\mathrm{DB} / \mathrm{DC}(\%)$ & 1983 DB Only & Matched DC & $\mathrm{DB} / \mathrm{DC}(\%)$ \\
\hline Mean & 8,938 & 34,766 & 25.71 & 20,003 & 43,473 & 46.01 \\
\hline Median & 5,565 & 27,510 & 20.23 & 14,366 & 34,587 & 41.54 \\
\hline $10^{\text {th }}$ Percentile & 0 & 8,548 & 0.00 & 2,849 & 10,392 & 27.42 \\
\hline $90^{\text {th }}$ Percentile & 20,293 & 70,635 & 28.73 & 41,944 & 89,368 & 46.93 \\
\hline Std. Deviation & 13,031 & 27,513 & & 20,446 & 34,230 & \\
\hline
\end{tabular}

\section{Notes:}

1) All amounts are in 1983 dollars (CPI97/CPI83 = 1.61) and represent the level of the actuarial present value of vested DB pension benefits or the balance in the DC pension account at turnover.

2) The left column in each panel is the distribution of pension wealth from the actual sample of plans covering the SCF 1983 sample respondents. The middle column is the distribution of pension wealth from the matched sample of 1995 DC plans. The right column is the ratio of the DB wealth to the DC wealth.

3) The 1983 sample of 46,045 observations is 60.2 percent DB plan only, 17.4 percent DC only, and 22.4 percent with a combination of DB and DC plans.

4) The baseline assumptions assume a $10 \%$ standard deviation of the permanent shock to earnings each year, a $1.5 \%$ rate of annual productivity growth, and historical rates of return on assets. 


\section{Appendix A: Correspondence Between the SCF and the Current Population Survey}

Summary statistics for those contribution rates from the 1989, 1992, and 1995 SCFs are presented in Table A.1. Also presented are tabulations for 1988 and 1993 from the Current Population Survey Employee Benefits Supplements from EBRI (1994). ${ }^{21}$

The first three rows show that approximately 27.8 percent of the workers in the SCF 1995 were covered by a DC plan, up from 21.0 percent in the SCF 1992 and 18.0 percent in the SCF 1989. The next rows describe the rates and levels of employee contributions. In $1995,78.8$ percent of the covered workers made a contribution to their plans, down from 81.4 percent in 1989. The CPS numbers show the same trend but at a lower level. Average employee contributions (including those who did not contribute) were 5.3 percent of earnings or $\$ 2,502$ in 1995 and totaled $\$ 71.8$ billion in aggregate. The CPS 1993 shows a slightly lower contribution rate of 4.9 percent and $\$ 1,971$ on average and a much lower aggregate total of $\$ 49.6$ billion. $^{22}$ Other years match up more closely between the SCF and CPS samples.

According to the SCF in 1995, 72.3 percent of employers made contributions. The average percent contributed was 5.0 percent, with an average dollar value of $\$ 2,160$ and aggregate contributions of $\$ 62.0$ billion. The EBRI (1994) tabulations do not present employer contributions explicitly, but they do provide a range for the percent of employers who provide any contributions; the SCF estimates are inside the relevant ranges. Overall, the two data sources suggest a fairly high level of participation and contribution to tax-deferred savings

\footnotetext{
${ }^{21}$ In order to compare the contribution rates with the CPS, we include all thrift plans in the table, whether or not the worker also has another pension plan. In our simulations, we sample only from the set of individuals for whom the thrift plan is the only employer-sponsored retirement plan.

${ }^{22}$ The greater disparity in the totals than the average is presumably related to the over-sampling of high-income workers in the SCFs. Even with appropriate sample weights in each survey, the SCF is likely to do a better job of characterizing values like pension contributions that increase with income.
} 
accounts over the last ten years. ${ }^{23}$

Table A.1

Thrift Plans in SCF 1989, 1992, and 1995, With Comparisons to CPS 1988 and 1993

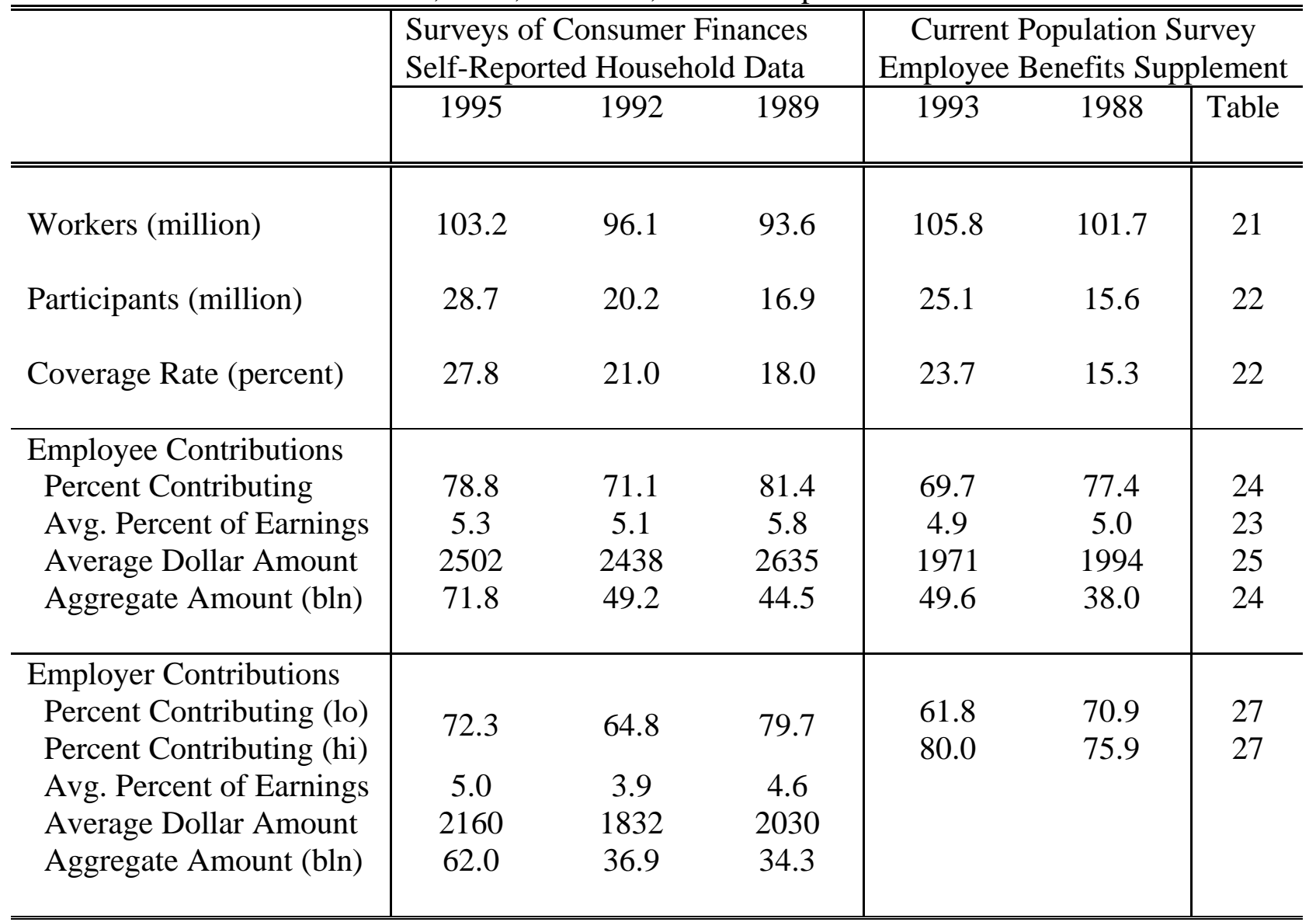

Notes:

1) The SCF samples include all respondents and spouses that are currently employed. The sample in the CPS includes all civilian, nonagricultural workers over age 16.

2) The column marked "Table" refers to the table number in EBRI (1994) that is the basis for the statistic in each row.

3) All monetary amounts are expressed in constant 1995 dollars.

4) Contribution rates in the SCF are prorated so that the total of employer and employee contributions is no more than the minimum of $\$ 30,000$ and 25 percent of earnings.

\footnotetext{
${ }^{23}$ When necessary, we impose both dollar and percentage limits on the contributions to all DC plans and thrift plans in all years (including 1983 in the simulations below) that are consistent with the current law for DC plans, as documented in McGill et al (1997). Contribution rates are prorated so that the total of employer and employee contributions is no more than the lesser of 25 percent of earnings and $\$ 30,000$, with the dollar amount indexed to inflation in future years.
} 


\section{Appendix B: Imputations of Pension Plans Not Found in Pension Provider Survey}

Only 73 percent of the respondents to the SCF 1983 who reported pension coverage could be linked to a pension plan in the Pension Provider Survey. This censoring is not random-workers at smaller firms are less likely to have their plans in the PPS, while public sector workers are more likely to have their plans in the PPS. We used a hot decking procedure to overcome the sample selection bias that results if the censoring probability is not uncorrelated with the generosity of the pension plan. For each person whose pension plan is not found, the plan of a person with similar characteristics whose plan is found is substituted. That plan is chosen according to the following procedure. If any step in the procedure would eliminate all remaining plans, then that step is not taken, but the procedure continues.

\section{1) Employer Type}

The set of respondents with plans in the PPS is first sorted according the type of employer: federal government, state/local government, public school/college, private school, military, private employers with greater than 100 employees, and private employers with fewer than 100 employees. Military plans are imputed as their own group without further disaggregation.

\section{2) State of Residence}

The set of respondents who work for state/local governments and public schools/colleges are sorted according to state of residence. For these purposes, the high-income sample is treated as if it were its own state of residence.

\section{3) Social Security Coverage}

All categories (except for federal government employees) are sorted according to whether the respondent reports being covered by Social Security in addition to the employer-provided 
pension. As of 1983, some workers (generally public sector employees) were not covered by Social Security. The pension plans for these workers are designed to provide benefits comparable to the pension and Social Security benefits of comparable private sector workers. 4) Union, Industry, Occupation

All categories are then further disaggregated first by union coverage, then by 1-digit industry code, and lastly by 1-digit occupation code.

At the end of these four steps, each respondent whose plan is not found in the PPS has a set of possible matches among the plans of those respondents with matching characteristics whose plans are found in the PPS. One of these plans is randomly allocated to the censored respondent. This procedure will remove any sample selection bias that is the result of the full interaction of employer type (including state and Social Security coverage where applicable), union coverage, industry, and occupation. This procedure will not remove the bias that may result from censoring within these categories. 


\section{Appendix C: Modifications to Original Pension Provider Survey Code (Version 3)}

The PPS 1983 documentation in Curtin (1987) also provides programs that calculate pension entitlements based on the data in the SCF and the PPS. They are sufficiently general so that entitlements can be computed under a variety of economic assumptions for any individual in the SCF or hypothetical worker. Nearly identical programs for the PPS 1989 were obtained from the Survey Research Center at the University of Michigan. The modifications of these programs discussed below are designed to enhance their technical and economic applications. All changes refer to both years of the surveys.

\section{1) PC Compatibility}

The first modification was purely technical; to change the syntax and file structure so that the programs could be used on any PC. The original programs are written in a version of PASCAL tailored to the University of Michigan MTS mainframe computer. This language also compiles on an IBM RS/6000, which was used to generate the simulations in this paper. In the interest of making the pension software available to a wider community of users, the original versions have been rewritten in Turbo Pascal, which can compile easily on a PC.

The original programs were designed in two stages. The first set read the information on the pension plans from the PPS dataset and created procedures for each plan. The key step is to parse the literal formula codes and generate programming statements from them. The second set of programs read in the information on the plan participants from the SCF and used the code generated by the first set of programs to compute entitlements. It was possible to adapt only this second set of programs to the PC; the pension procedures were generated by the mainframe version and each of the 1011 (1983) or 798 (1989) procedures must be edited individually (but systematically!) in order to consider fundamental changes in the structure of pensions. The modifications to Final Average 
Pay calculations and the indexing of nominal amounts to wage growth discussed below were made this way. PC-compatible versions of these original programs are available from the authors upon request. The remaining points refer to the programs as they have been modified for this paper.

\section{2) More General Earnings Profiles}

The original programs allow for an economy wide growth rate and an individual specific growth rate. The individual's growth rate must remain constant over his entire career, which is an unrealistic assumption. In particular, it does not simultaneously allow for high wage growth during early years on the job and declining (and even negative) wage growth in later years. In order to incorporate variable wage growth over the life-cycle, the coefficients from cross-sectional wage regressions are used. In this paper, we use a quartic in age estimated on the 1983 Current Population Survey for full-time workers between the ages of 16 and 64 to forecast real earnings.

\section{3) Computation of Social Security Benefits}

Many plans are integrated with Social Security either through the expected benefits (Offset plans) or the maximum taxable earnings amount (Excess plans). In the original versions, all calculations were based on the average benefit, average covered wage (ACW), and Maximum Taxable Earnings (MTE) as of 1983. Individuals who had current wages above the ACW but below the MTE were assigned the average benefit. Those with less than the ACW received half the average benefit, while those with more than the MTE received 150 percent of the average benefit. In the new versions, the actual Social Security benefit formulas (and the more realistic wage growth rates) are used so that true variation in the offset rates is revealed in the computed entitlements. Additionally, all changes in the Social Security benefit formulas made in 1983 have been incorporated, so that the effect of those changes on entitlements and retirement can be assessed. 


\section{4) Calculation of Final Average Pay}

Most DB pensions that are based on final average pay calculate FAP as the average of the highest or highest consecutive years of earnings during some specified period. For example, the highest five years of earnings during the last ten is quite common. When nominal earnings are always increasing with age, which was the case when wage growth was uniform over the lifetime, this formula reduced to the last five years of earnings. The original programs calculated FAP in this simplified way. However, when a more general specification of the wage equation is used, it is possible for nominal earnings at older ages to decline. The simplified FAP calculation would understate FAP (and therefore pension benefits) in such cases. The modified programs compute FAP in the precise way specified in the summary plan description so that this does not occur.

\section{5) Indexation of Nominal Amounts}

Since pension formulas are adjusted periodically in line with the firm's overall financial position (and must be included in all collective bargaining arrangements), it is unreasonable to believe that a formula that promises, say, \$20 per month in benefits for every year worked will remain at \$20 in nominal terms into the indefinite future. A more likely scenario is that the overall generosity of the benefits will increase in line with price or wage growth. In the current version of the programs, every such nominal amount is augmented by a user-specified growth rate.

\section{6) Incorporation of Pension Reforms}

The direct effects of the various pension reforms during the 1980s are now phased in conditional on the date as of which the benefits are being computed. For example, TEFRA (1982), DEFRA (1984), and TRA (1986) all set limits on the current or future maximum covered wages, benefits payable, and contributions possible for qualified plans. 